\title{
A review of World species of the genus Pleurochaetella Vockeroth, 1965 (Diptera: Scathophagidae)
}

\author{
Обзор видов рода Pleurochaetella Vockeroth, 1965 \\ (Diptera: Scathophagidae) мировой фауны
}

\author{
A.L. Ozerov ${ }^{1}$, M.G. Krivosheina ${ }^{2}$ \\ А.А. Озеров ${ }^{1}$, М.Г. Кривошеина ${ }^{2}$

\begin{abstract}
'Zoological Museum, Moscow Lomonosov State University, Bol'shaya Nikitskaya 6, Moscow 125009, Russia.
E-mail: ozerov2455@rambler.ru

'Зоологический музей, Московский государственный университет им. М.В. Ломоносова, Большая Никитская ул., 6, Москва 125009 , Россия.

${ }^{2}$ A.N. Severtzov Institute of Ecology and Evolution, Russian Academy of Sciences, 119071 Moscow, Russia.

E-mail: dipteramarina@rambler.ru

${ }^{2}$ Институт проблем экологии и эволюции им. А.Н.Северцова РАН, Ленинский проспект, 33, Москва 119071, Россия.
\end{abstract}

ABSTRACT. Flies of the genus Pleurochaetella Vockeroth, which includes two species, are reviewed. One of them, new to science, Pleurochaetella barkalovi Ozerov, is described and the other species, $P$. simplicipes (Becker, 1900), is redescribed. Genus diagnosis, keys for determination of species are given, and data on distribution are summarized.

РЕЗЮМЕ. Дан обзор двукрылых рода Pleurochaetella Vockeroth, в состав которого входят два вида. Приведено описание Pleurochaetella barkalovi Ozerov, нового для науки вида, и переописание другого вида, P. simplicipes (Becker, 1900). Даны диагноз рода и ключ для определения видов Pleurochaetella, а также суммированы данные по распространению видов.

\section{Introduction}

Pleurochaetella Vockeroth, 1965 is one of the small genera within the family Scathophagidae, which until the present time has comprised single Holarctic species - P. simplicipes [Becker, 1900]. The species of Pleurochaetella are sparsely distributed in arctic tundra. Engelmark [1997] defines $P$. simplicipes as "arctic species rarely found south of the tree line (euarctic and hemiarcric species)". The American distribution is mapped in Vockeroth [1958]. Nothing is known about the biology of species.

Terminology follows McAlpine [1981] and Cumming et al [2009], except that "postpedicel" is used for antennal flagellomere 1 (third antennal segment) [Stuckenberg, 1999].

The following abbreviations are used for depositories of the studied specimens: ISEA — Siberian Zoological Museum, Institute for Systematics and Ecology of Animals, Siberian Branch of the Russian Academy of Sciences, Novosibirsk, Russia; MZH Finnish Museum of Natural History, Helsinki, Finland;
OSU — Ohio State University, Ohio, Columbus, USA; ZISP - Russian Academy of Sciences, Zoological Institute, St. Petersburg, Russia; ZMUM - Zoological Museum, Moscow State University, Moscow, Russia.

Other abbreviations used: $a$ - anterior; $d-$ dorsal; $p$ - posterior; $v$ - ventral, and combinations of these latter four, all used for leg chaetotaxy.

\section{Taxonomic part}

Pleurochaetella Vockeroth

Pleurochaeta Becker, 1915: 63. Gender: feminine. Junior secondary homonym, preoccupied by Pleurochaeta Beddard, 1883. Type-species: Pleurochaeta fulvisetis Becker, 1915 [= simplicipes (Becker, 1900)], by monotypy.

Pleurochaetella Vockeroth, 1965: 834. Gender: feminine. New name for Pleurochaeta Becker. Type-species: Pleurochaeta fulvisetis Becker, 1915 [= simplicipes (Becker, 1900)], automatic.

DIAGNOSIS. Postpedicel with acute upper apical corner. Arista bare. Palpus distinctly spatulate. Proepisternum covered with hair-like setulae at middle or in anterior part. Anepisternum covered with setulae usually along dorsal margin and in posterior part only, without setulae posterior to anterior spiracle. Anepimeron bare. Katepisternum with 1 strong seta in posterodorsal corner.

Postmetacoxal (= postcoxal, metepimeral) bridge absent. Scutellum with 2 pairs of strong setae: basal and apical. Fore tibia of both sexes with posteroventral rows of short setae. Wing membrane emarginate between $\mathrm{M}_{1}$ and $\mathrm{CuA}_{1}$, in male margin here with long fringe of hairs (Figs 5, 6). Male sternites 3 and 4 laterally with pale hairs (Figs 9, 16). Male sternite 5 symmertical (Figs 10-11, 17-18). Cerci simple, symmerical (Figs 13, 20); surstyli asymmetrical (Figs 12-14, 19-21). Ovipositor short, slightly flattened laterally (Figs 2-4), tergites 7 and 8 divided medially (Fig. 2). 

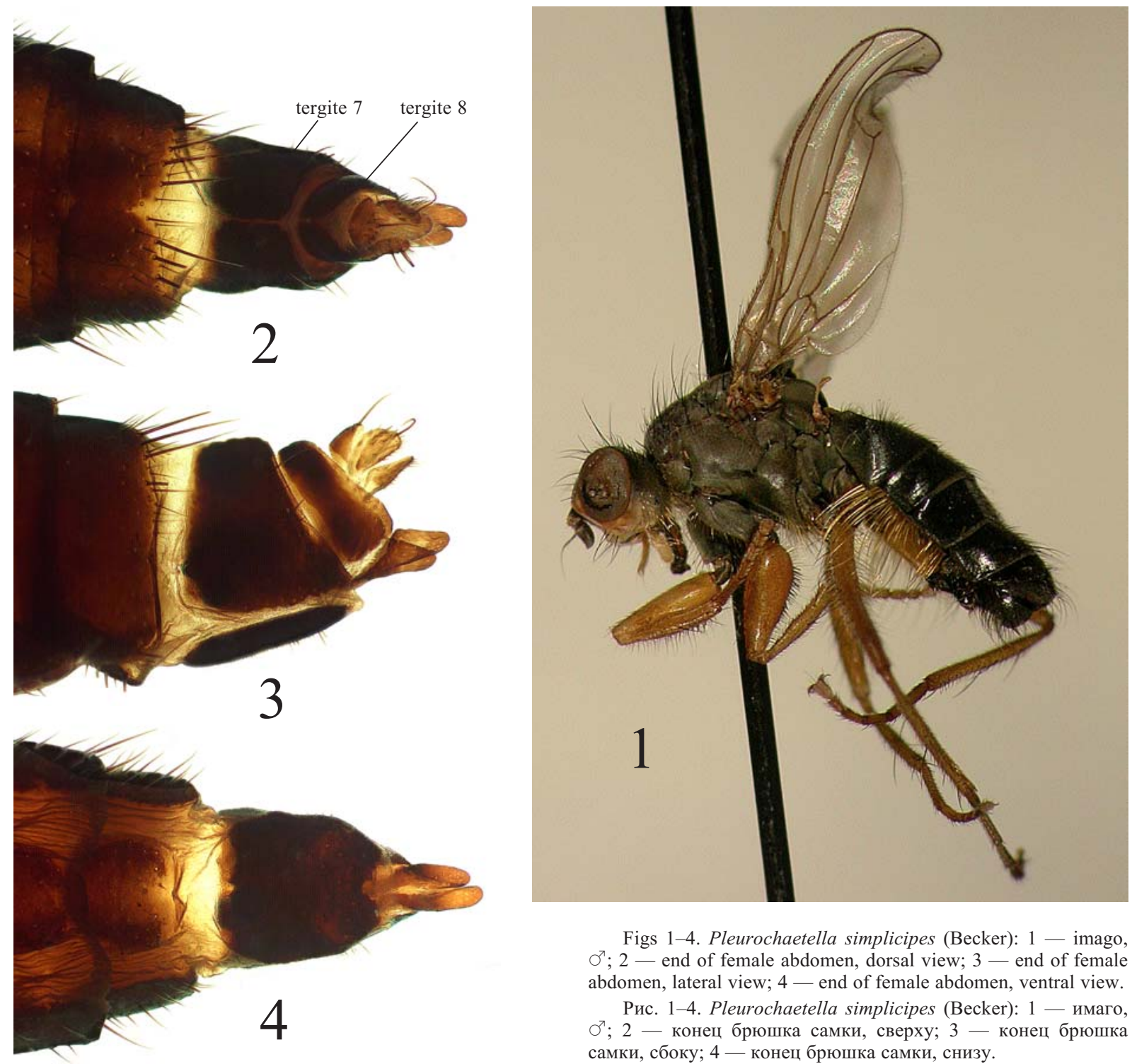

Figs 1-4. Pleurochaetella simplicipes (Becker): 1 - imago, $\mathrm{O}^{\top} ; 2$ - end of female abdomen, dorsal view; 3 - end of female abdomen, lateral view; 4 - end of female abdomen, ventral view.

Pис. 1-4. Pleurochaetella simplicipes (Becker): 1 - имаго, $0^{7} ; 2$ - конец брюшка самки, сверху; 3 - конец брюшка самки, сбоку; 4 - конец брюшка самки, снизу.

\section{Pleurochaetella simplicipes (Becker)}

Figs 1-5, 8-14.

simplicipes Becker, 1900: 50 (Cosmetopus). Type-locality: Dudinka (Russia, Krasnoyarskiy Kray); LT $\sigma^{7}$, by designation of Andersson, 1974: 101, in MZH.

fulvisetis Becker, 1915: 64 (Pleurochaeta). Type-locality: “ausdem Polaren Ural" (Russia); HT $\sigma^{7}$, in ZISP.

dissimilis Malloch, 1920a: 286 (Microprosopa). Type-locality: "Katmai, Alaska" (USA); HT + , in OSU.

MATERIAL EXAMINED. CHUKOTKA: Anadyr' Distr., Meynipyl'gino (62.538562N, 177.051967E), 26-29.VI. and 313.VII.2012, P.S. Tomkovich (2 $\sigma^{\top}, 1$, in ZMUM); KRASNOYARSKIY KRAY: Taimyr, Taimyr Biosphere Reserve, Ary-Mas field station $\left(72.5^{\circ} \mathrm{N}, 101.94^{\circ} \mathrm{E}\right), 14 \mathrm{~m}, 9-11 . \mathrm{VII} .2010$, A. Barkalov [labels in Russian] ( $1 \sigma^{\top}, 1$ \%, in ISEA); Taimyr, Taimyr Biosphere Reserve, Ary-Mas field station $\left(72.5^{\circ} \mathrm{N}, 101.94^{\circ} \mathrm{E}\right), 14 \mathrm{~m}, 19 . \mathrm{VII} .2010$ O. Chruleva [labels in Russian] (4 $\sigma^{7} \sigma^{7}$, in ZMUM); Taimyr, Zakharova Rassokha $\left(72.7^{\circ} \mathrm{N}, 101.08^{\circ} \mathrm{E}\right), 1 . \mathrm{VII} .2011, \mathrm{~V} \mathrm{~K}$. Zinchenko [labels in Russian] (5 $\sigma^{\top} \sigma^{7}, 4$ 0 , in ISEA and ZMUM); N.-W. Taimyr penn., $12.5 \mathrm{~km} \mathrm{~S}$. Dixon settl. (73² $\left.24^{\prime} \mathrm{N}, 80^{\circ} 39^{\prime} \mathrm{E}\right)$, bank of
Lemberova River, 26.VII.2012, Coll. A.Barkalov (1 ๑7, in ISEA); YAKUTIA: Gulf Coast Olenek, pos. Ystannach-Khocho, $\left(72.58^{\circ}\right.$ N, $121.42^{\circ}$ E), 20.VIII.2010, A. Yadrenkin (1 $\sigma^{7}$, in ZMUM).

REDESCRIPTION. Male (Fig. 1), female. Length of body $5.2-6.0 \mathrm{~mm}$, length of wing $4.2-4.8 \mathrm{~mm}$.

Head. Fronal vitta black, but yellow in anterior half or third, matt. Fronto-orbital plate and ocellar triangle black, greyish microtrichose. Parafacial, face and gena yellow, with white microtrichia. Postcranium black, greyish microtrichose, with black setae in upper third and yellowish setae and hairs in lower part. Setae: 3 orbitals, 2-3 frontals, 1 ocellar (weak), 1 postocellar, 1 inner vertical, 1 outer vertical; 2 pairs of strong vibrissae. Antenna black, postpedicel with slightly acute dorsoapical corner, approximately 1.2 times as long as wide. Arista bare. Palpus yellow, with long (male) or moderate long (female) yellow setae.

Thorax black, greyish microtrichose. 2 postpronotals, 2 notopleurals, supra-alars $1+2$, intra-alars $1+2$ 

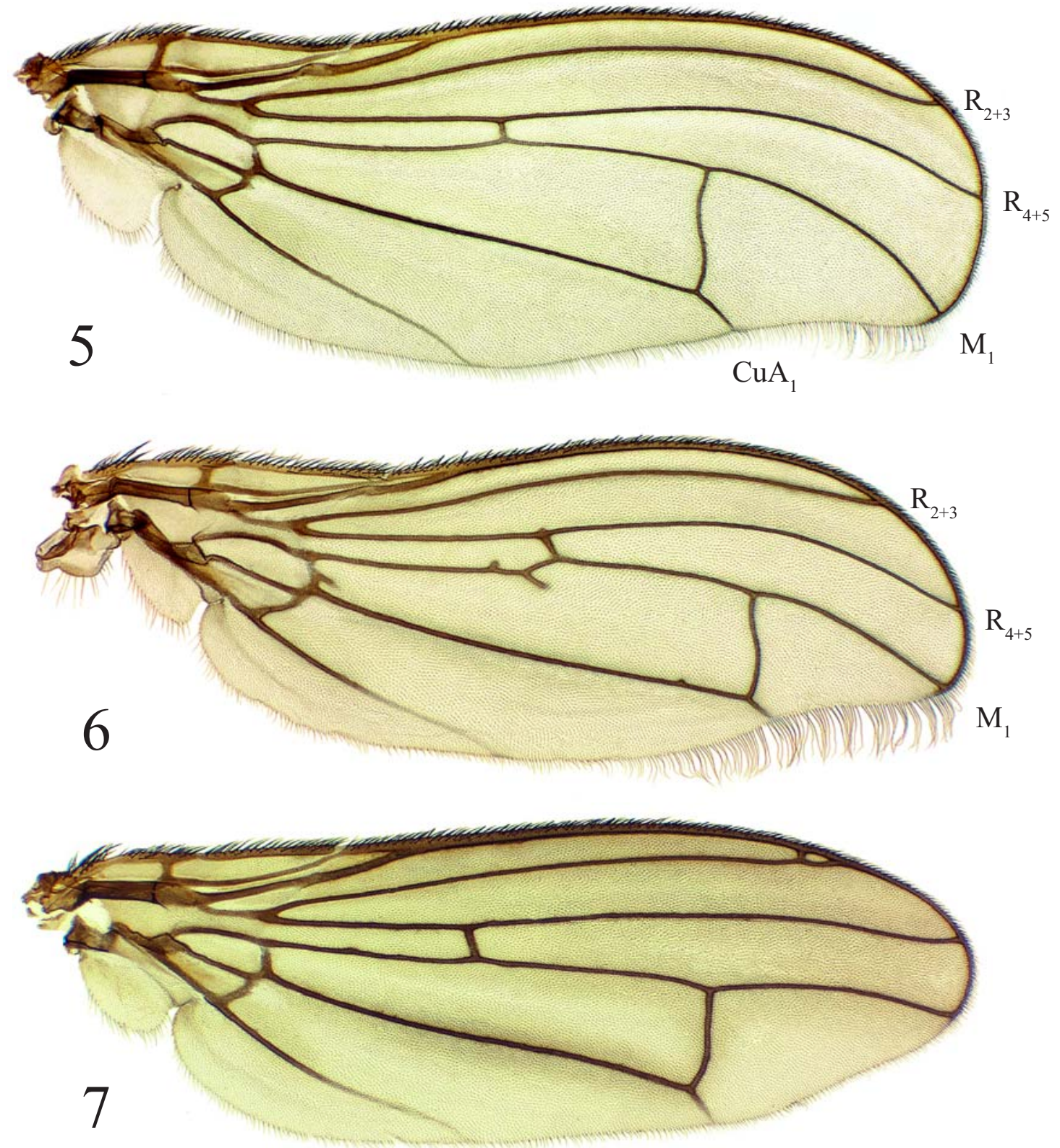

Figs 5-7. Pleurochaetella spp. wing: $5-$ P. simplicipes (Becker), O'; $6-$ P. barkalovi sp.n., O'; $7-$ P. barkalovi sp.n., + . Pис. 5-7. Pleurochaetella spp. крыло: 5 - P. simplicipes (Becker), $\sigma^{7} ; 6-$ P. barkalovi sp.n., $\bigcirc^{7} ; 7-$ P. barkalovi sp.n.,, .

(usually very weak), 2 postalars, dorsocentrals $3+3$, the anterior presutural directed to head; acrostichal setulae in two rows. Proepisternum covered with hair-like setulae at middle part, with 1 seta near lower margin. Proepimeron without seta. Anepisternum covered with setulae along dorsal margin and in posterior part only, with 2-5 setae near posterior margin. Katepisternum covered with long (male) or moderate long (female) yellow hairs, with strong black seta in posterodorsal corner. Anepimeron bare. Postmetacoxal bridge absent. Scutellum with 2 basal and 2 apical setae.

Legs yellow, but all coxae and trochanters black. Fore femur as in Fig. 8. Fore tibia with rows of short spines ventrally, with $1 p$ and $1 d$ at middle, and preapi- cals $d, p$ and $p d$. Mid femur with irregular rows of $p v$, $a v$ and $a d$ setae and 2 preapical $p$. Mid tibia with $1 a d$, $1 p d$ and $1 p$ at middle and ring of apical setae. Hind femur with rows of $a d, p v$ and $a v$ setae, in male with long yellow hairs in basal half posteroventrally, but shorter in female. Hind tibia with $2 a d, 2 p d, 1 a v$, preapicals $d$ and $a d$, and 1 apical $a v$.

Wing tinged with brownish. Veins brown, crossveins not darkened. Costal sector between $\mathrm{R}_{2+3}$ and $\mathrm{R}_{4+5}$ shorter or subequal than between $\mathrm{R}_{4+5}$ and $\mathrm{M}_{1}$ (Fig. 5). Wing membrane emarginate between $\mathrm{M}_{1}$ and $\mathrm{Cu} \mathrm{A}_{1}$, in male margin here with fringe of hairs (Fig. 5). Calypters, including margins, and halteres brownish. 

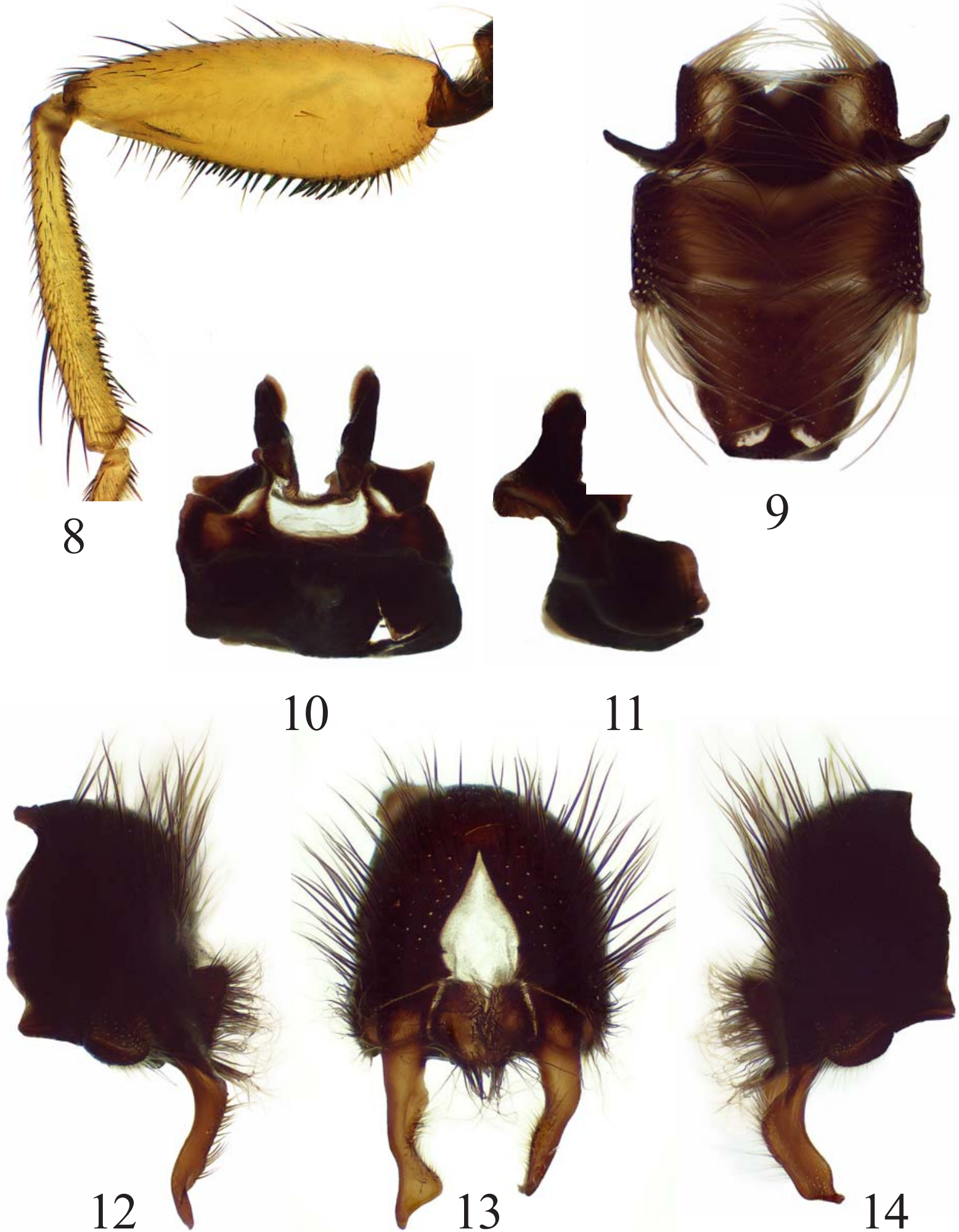

Figs 8-14. Pleurochaetella simplicipes (Becker), ơ : 8 - right fore leg, anterior view; 9 - sternites 2-4; 10 - sternite 5, dorsal view; 11 - sternite 5, lateral view; 12 - epandrium, cerci and left surstylus, lateral view; 13 - epandrium, cerci and surstyli, dorsal view; 14 epandrium, cerci and right surstylus, lateral view.

Рис. 8-14. Pleurochaetella simplicipes (Becker), ơ': 8 - передняя правая нога, спереди; 9 - стерниты 2-4; 10 - стернит 5, сверху; 11 - стернит 5, сбоку; 12 - эпандрий, церки и левый сурстиль, сбоку; 13 - эпандрий, церки и сурстили, сверху; 14 эпандрий, церки и правый сурстиль, сбоку. 
Abdomen black, with whitish-grey dust, densely in female, in both sexes covered with black hairs. Male sternites 3 and 4 laterally with long pale hairs (Fig. 9). Male sternite 5 as in Figs 10, 11. Epandrium, cerci and surstyli as in Figs 12-14; surstyli asymmetrical.

DISTRIBUTION. North of Scandinavia and Russia, (?)Mongolia [Gorodkov, 1986]; North of North America: from Alaska to Labrador [Vockeroth, 1958, 1965].

\section{Pleurochaetella barkalovi Ozerov, sp.n.} Figs 6, 7, 15-21.

MATERIAL. Holotype $\sigma^{\prime}$, RUSSIA: KRASNOYARSKIY KRAY: N.-W. Taimyr pen., $12.5 \mathrm{~km}$ S. Dixon settl. $\left(73^{\circ} 24^{\prime} \mathrm{N}\right.$, $80^{\circ} 39^{\prime} \mathrm{E}$ ), bank of Lemberova River, 6-26.VII.2012, Coll. A. Barkalov (in ISEA). Paratypes: $8 \mathrm{O}^{7} \mathrm{O}^{2}, 4$ 우, same label as holotype (in ISEA and ZMUM);

DESCRIPTION. Male, female. Length of body 5.1$5.8 \mathrm{~mm}$, length of wing $3.5-4.2 \mathrm{~mm}$.

Head. Fronal vitta black, but yellow in anterior half or third, matt. Fronto-orbital plate and ocellar triangle black, greyish microtrichose. Parafacial, face and gena yellow, with white microtrichia, some females with face and parafacial darkened. Postcranium black, greyish microtrichose, with black setae in upper third and yellowish setae and hairs in lower part. Setae: 3 orbitals, 2-3 frontals, 1 ocellar (weak), 1 postocellar, 1 inner vertical, 1 outer vertical; 2 pairs of strong vibrissae. Antenna black, postpedicel with slightly acute dorsoapical corner, approximately 1.2 times as long as wide. Arista bare. Palpus yellow (in female usually with darkened apex), with long (male) or moderately long (female) yellow setae.

Thorax black, greyish microtrichose. 2 postpronotals, 2 notopleurals, supra-alars $1+2$, intra-alars $1+2$ (usually very weak), 2 postalars, dorsocentrals (3-4)+3, the anterior presutural directed to head; acrostichal setulae in two rows. Proepisternum covered with hair-like setulae at middle part, with 1 seta near lower margin. Proepimeron with or without seta near lower margin. Anepisternum covered with setulae along dorsal margin and in posterior part only, with 2-5 setae near posterior margin. Katepisternum covered with moderately long yellow hairs, with strong black seta in posterodorsal corner. Anepimeron bare. Postmetacoxal bridge absent. Scutellum with 2 basal and 2 apical setae.

Legs yellow, but all coxae and trochanters black. Fore femur as in Fig. 15. Fore tibia with rows of short spines ventrally, with $1 p$ and $1 d$ at middle, and preapical $d, p$ and $p d$. Mid femur with irregular rows of $p v$, $a v$ and $a d$ setae and 2 preapical $p$. Mid tibia with $1 a d$, $1 p d$ and $1 p$ at middle and ring of apical setae. Hind femur with rows of $p v$ and $a v$ setae. Hind tibia with 2 $a d, 2 p d, 1 a v$, preapical $d$ and $a d$, and 1 apical $a v$.

Wing tinged with brownish. Veins dark brown to black, crossveins not darkened. Costal sector between $\mathrm{R}_{2+3}$ and $\mathrm{R}_{4+5}$ longer than between $\mathrm{R}_{4+5}$ and $\mathrm{M}_{1}$ (Figs 6, 7). In male $\mathrm{M}_{1}$ posteriorly usually with supernumerary, imperfect crossvein (Fig. 6). Wing membrane emarginate between $\mathrm{M}_{1}$ and $\mathrm{CuA}_{1}$, in male margin here with long fringe of hairs (Fig. 6). Calypters, including margins, and halteres brownish.
Abdomen black, with whitish-grey dust, densely in female, in both sexes covered with black hairs. Male sternites 3 and 4 laterally with short pale hairs (Fig. 16). Male sternite 5 as in Figs 17, 18. Epandrium, cerci and surstyli as in Figs 19-21; surstyli asymmetrical.

DISTRIBUTION. RUSSIA: Krasnoyarskiy Kray, Taymyr Peninsula.

ETYMOLOGY. The new species is named after the collector, Russian dipterologist Anatoly V. Barkalov.

\section{Key to species of Pleurochaetella}

1. Wing: costal sector between $\mathrm{R}_{2+3}$ and $\mathrm{R}_{4+5}$ longer than between $R_{4+5}$ and $M_{1}$ (Figs 6, 7). Male sternites 3 and 4 laterally with short pale hairs (Fig. 16); epandrium, cerci and surstyli as in Figs 19-21 ...P. barkalovi Ozerov, sp.n.

- Wing: costal sector between $\mathrm{R}_{2+3}$ and $\mathrm{R}_{4+5}$ shorter or subequal to sector between $\mathrm{R}_{4+5}$ and $\mathrm{M}_{1}^{2+3}$ (Fig. 5). Male sternites 3 and 4 laterally with long hairs (Fig. 9); epandrium, cerci and surstyli as in Figs 12-14 ............. P. simplicipes (Becker)

ACKNOWLEDGMENTS. I wish to thank Dr. Anatoly Barkalov (ISEA) for the material of Scathophagidae from Taymyr.

\section{References}

Andersson H. 1974. Revision of the North European species of Cosmetopus Becker (Dipt. Scatophagidae) // Entomologica Scandinavica Vol.5. P.95-102.

Becker Th. 1900. Beiträge zur Dipteren-Fauna Sibiriens. Nordwest-Sibirische Dipteren gesammelt vom Prof. John Sahlberg aus Helsingfors im Jahre 1876 und vom Dr. E. Bergroth aus Tammerfors im Jahre 1877 // Acta Societatis Scientiarum Fennicae. T.26. No.9. S.1-66.

Becker Th. 1915b. Cyclorrhapha schizophora. Holometopa // Becker Th., Dziedzicki H., Schnabl J., Villeneuve J. Résultats scientifiques de l'Expédition des frères Kuznecov (Kouznetzov) à l'Oural Arctique en 1909, sous la direction de H. Baklund. Livr.7. Diptera / Mém. Acad. Imp. Scie., Cl. Phys.-Mathém. Sér.8. T.28. No.7. P.63-67.

Cumming J.M., Wood D.M. 2009. Adult morphology and terminology // Brown B.V., Borkent A., Cumming J.M., Wood D.M., Woodley N.E., Zumbado M. (eds.). Manual of Central American Diptera. Vol. 1. National Research Council Press, Ottawa. P. 9-50.

Engelmark R. 1999. Dungflies (Diptera: Scathophagidae) collected by the Swedish-Russian tundra ecology expedition '94, with the description of two new species; Nanna indotatum and Cochliarium sibiricum // Entomologisk Tidskrift. Arg.120. Häft 4. P.157-167.

Gorodkov K.B. 1986. Family Scathophagidae // Soós Á, Papp L. (eds.). Catalogue of Palaearctic Diptera. Vol.11. Scathophagidae-Hypodermatidae. Budapest: Akadémiai Kiadó. P.11-41.

Malloch J.R. 1920a. XII. Descriptions of Diptera of the families Anthomyidae and Scatophagidae // The Ohio Journal of Science. Vol.20. No.7. P.267-391.

McAlpine J. F. 1981. Morphology and terminology-adults // McAlpine J.F., Peterson B.V., Shewell G.E, Teskey H.J., Vockeroth J.R., Wood D.M., Coordinators. Manual of Nearctic Diptera. Vol.2. Research Branch. Agriculture Canada. Monograph 27, Ottawa. P.9-63.

Stuckenberg B.R. 1999. Antennal evolution in the Brachycera (Diptera), with a reassessment of terminology relating to the flagellum // Studia Dipterologica. Vol.6. S.33-48.

Vockeroth J.R. 1958. Distribution patterns of the Scatomyzinae (Diptera, Muscidae) // Proceedings of the Tenth International Congress of Entomology, Montréal, Que., 17-25 August 1956. Vol. 1. Mortimer Ltd., Ottawa, Ont. P.619-625.

Vockeroth J.R. 1965. Subfamily Scatophaginae // Stone A. et al. (eds.). A catalog of the Diptera of America north of Mexico. U.S.D.A., Agriculture Handbook. No 276. P.826-842. 


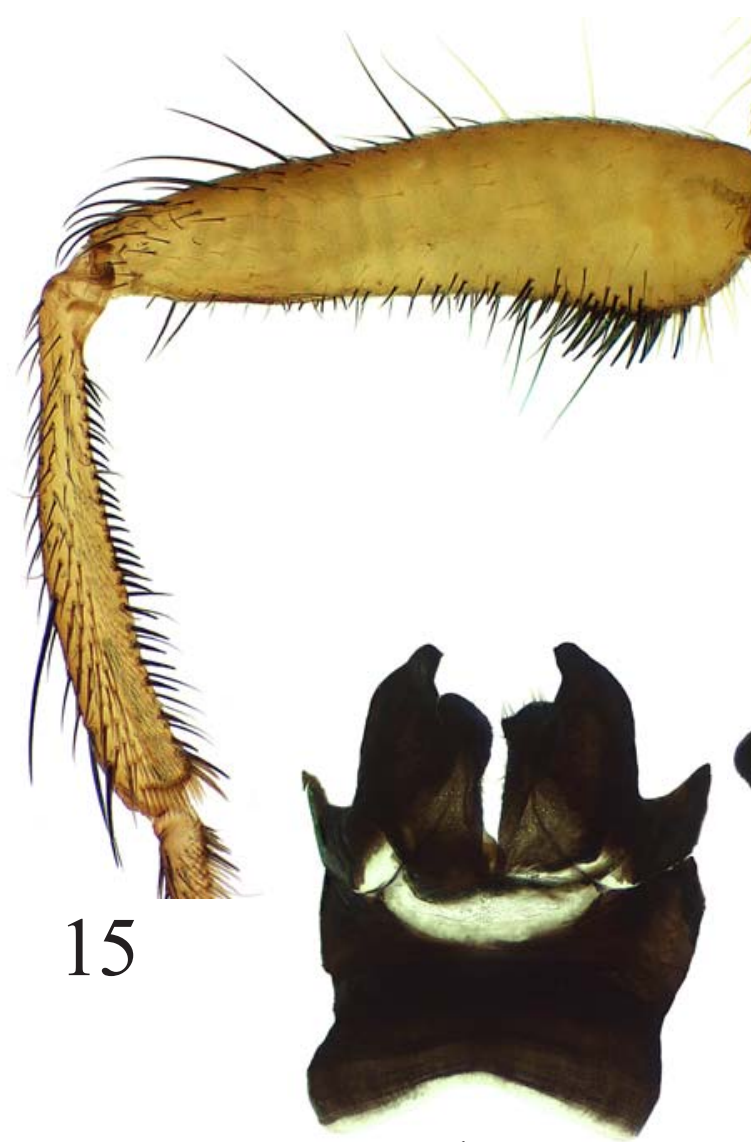

17
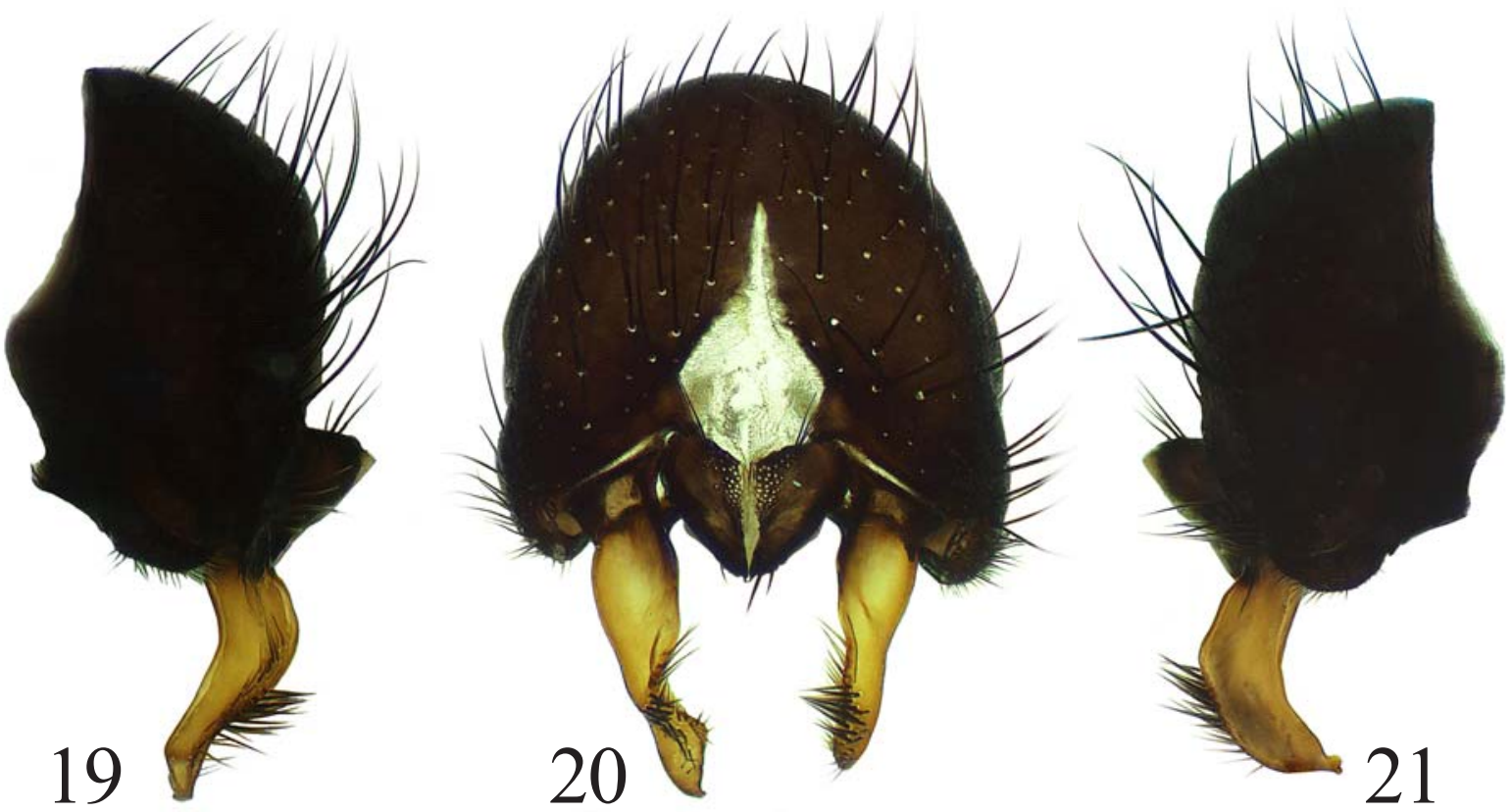

Figs 15-21. Pleurochaetella barkalovi Ozerov, sp.n., O': 15 - right fore leg, anterior view; 16 - sternites 3 and 4; 17 - sternite 5, dorsal view; 18 - sternite 5, lateral view; 19 - epandrium, cercus and left surstylus, lateral view; 20 - epandrium, cerci and surstyli, dorsal view; 21 - epandrium, cercus and right surstylus, lateral view.

Рис. 15-21. Pleurochaetella barkalovi Ozerov, sp.n., o': 15 - передняя правая нога, спереди; 16 - стерниты 3 и 4; 17 стернит 5, сверху; 18 - стернит 5, сбоку; 19 - эпандрий, церк и левый сурстиль, сбоку; 20 - эпандрий церки и сурстили, сверху; 21 - эпандрий, церк и правый сурстиль, сбоку. 